\title{
EVALUATION OF MICROSOFT EXCEL SOLVER AS A TOOL FOR ADSORPTION KINETICS DETERMINATION
}

\author{
Adekunbi $^{2}$ E. A., Babajide 2 , J. O., Oloyede ${ }^{2}$, H. O., Amoko², J. S., Obijole, ${ }^{2}$ O. A. and \\ $\mathrm{Oke}^{1}$ I. A.
}

${ }^{1}$ Department of Civil Engineering, Obafemi Awolowo University, Ile-Ife, Nigeria (Currently on Sabatical leave at Department of Civil and Environmental Engineering, Elizade University, Ilara - Mokin, Ondo State)

${ }^{2}$ Department of Chemistry, Adeyemi Federal University of Education, Ondo, Nigeria.

Corresponding Author's Email: okeia@oauife.edu.ng

(Received: 20th June,2019; Accepted: 30th October, 2019)

\section{ABSTRACT}

\begin{abstract}
The paper contains a study of adsorption kinetics of lead ions on powdered corn cobs (PCCS). Corn cobs were collected within Obafemi Awolowo University, Ile-Ife, Nigeria, washed with distilled water, air dried, powdered and sieved into different particle sizes $(630-300 \mu \mathrm{m}, 300-212 \mu \mathrm{m}, 212-150 \mu \mathrm{m}$ and $150-75 \mu \mathrm{m})$ and stored for use. Lead solutions were prepared from lead salt using standard methods. Physical and chemical properties of PCCS, and adsorption kinetics of lead onto PCCS were studied. Effects of pH, particle size and initial lead concentrations on the kinetics models and their constants were studied and analysed using Analysis of Variance (ANOVA). Kinetics models' constants were determined using least square, graphical and Microsoft Excel Solver (MES) methods. Statistical evaluations of the three methods were conducted using Akaike Information Criterion (AIC) and Model of Selection Criterion (MSC). The study showed that moisture content of the PCCS was $7.29 \%$, volatile solid at $550^{\circ} \mathrm{C}$ was $96.88 \%$ and volatile solids at $1200^{\circ} \mathrm{C}$ was $99.44 \%$. Ash contents of the PCCS were $3.13 \%$, and $0.52 \%$ at $550^{\circ} \mathrm{C}$ and $1200^{\circ} \mathrm{C}$ respectively. Kinetics constants varied with $\mathrm{pH}$, particle size of the adsorbent and initial lead concentrations. The study showed that $\mathrm{pH}$, particle size and initial lead concentrations were significant factors that influence adsorption kinetics of lead ions on PCCS at $95 \%$ confidence level. It was concluded that the adsorption processes of $\mathrm{Pb}^{2+}$ onto the adsorbents followed two steps, mode of adsorption and transport are affected by more than one process. The order of accuracy of the methods was in Microsoft Excel Solver > Least Squared > Graphical method based on the value of MSC and AIC
\end{abstract}

Keywords: lead; adsorption kinetics; low-cost adsorbents; solution; adsorption

\section{INTRODUCTION}

The presence of heavy metals in wastewater at higher concentration is a significant environmental pollution problem due to the toxic effects and accumulation of these heavy metals throughout the food chain. Lead and cadmium are among the heavy metals that have higher priority for removal from aqueous environments than the other heavy metals (Amoko et al, 2016). The standard techniques for the removal of lead and cadmium from water and wastewaters include chemical precipitation, ion exchange, adsorption, membrane processes and distillation. Some of these techniques required high initial capital and operational costs (Ismail et al., 2009; Adie et al., 2009). These two factors make some of the techniques not practicable in developing countries like Nigeria and Kenya. These findings are the basis for the need for the development of innovative techniques with lower initial and operational cost. In the last three decade, efforts for new water and wastewaters treatment techniques had focused on adsorption and electrochemical methods (Amoko et al, 2016.

It has been reported that adsorption has many advantages over other treatment processes. The advantages are low capital and operational costs, the selective removal of metals, adsorbent regeneration and metal recovery potentiality, rapid kinetics of adsorption and desorption and small volume of sludge generation. Adsorption technology has been shown to be a feasible alternative for removing heavy metals from wastewater. This technology can utilize naturally abundant materials such as seaweeds (Amoko et al, 2016, Fehintola et al., 2015a) and powdered egg shell (Oke et al., 2008). Many researchers have studied adsorption of lead (II) and cadmium (II) from aqueous solutions using various biomasses. Yun et al. (1996) observed that the maximum uptake capacities of Durvillaea potatorum and 
Ecklonia radiata for $\mathrm{Pb}^{2+}$ were 1.6 and 1.3 $\mathrm{mmol} / \mathrm{g}$, respectively. More information on adsorption can be found in literature such as Erhan et al. (2004), Hanafiah et al. (2006), Izanloo and Nasseri (2005); Otun et al. (2006a and 2006b); Alam et al. (2007); Wuyep et al. (2007); Ho (2007); Adie et al. (2009); Oke et al. (2016).

Generally, in adsorption, equilibrium analysis, adsorption kinetics and mechanism are critical parameters. Kinetics analysis is fundamental for the evaluation of the affinity or capacity of an adsorbent. It is therefore, important to determine adsorption rates and its relationship with the concentrations of adsorbate in a solution. Many studies have been carried out to formulate a general expression describing the kinetics of adsorption on adsorbent surfaces for liquid-solid phase sorption systems. In recent years, sorption mechanisms have been reported and involved kinetic-based models. Some of the cited adsorption kinetics in literature are first-order kinetics and second-order kinetics. They also include reversible reactions, pseudo-first-order and pseudo- second order; reactions based on solution concentration and the Elovich model. The main objective of this study is to investigate the adsorption of lead (II) from aqueous environments using powdered corn cobs, with a particular attention to the kinetics.

\section{MATERIALS AND METHODS}

Corncobs were collected from an agricultural farm in Obafemi Awolowo University, Ile-Ife, Nigeria. The corncobs were washed with distilled water to remove impurities. The corncobs were dried at room temperature, ground into powder, sieved and classified using British Standard (BS) sieve. Powdered corncobs (PCCS) were selected based on its availability and based on previous studies (Fehintola et al., 2015a and b). Powdered corncob with sieve sizes of $<300 \mathrm{~m}\left(\mathrm{PCCS}_{1}\right), 300$ - $212 \mathrm{~m}\left(\mathrm{PCCS}_{2}\right), 212$ - $150 \mathrm{~m}\left(\mathrm{PCCS}_{3}\right)$ and $150-75$ $\mathrm{m}\left(\mathrm{PCCS}_{4}\right)$ were separated and stored in different desiccators. The mineral contents of the PCCS were determined by using spectrophotometer (Jenway 7315) after acid digestion of $2 \mathrm{~g}$ samples (2.0 $\mathrm{g}$ of cleaned PCCS was soaked in acid, APHA, 2012; van Loosdrecht et al., 2016). Selected properties (moisture content, ash content, and water and acid solubility) of the PCCS were determined using standard methods. Sample of PCCS was dried in an initially weighed dish at $105^{\circ} \mathrm{C}$ to a constant weight in an oven (APHA, 2012, Fehintola et al., 2015b). The moisture content $\left(\mathrm{M}_{\partial}\right)$ of PCCS was computed as follows:

$M_{c}(\%)=100\left(\frac{W_{1}-W_{2}}{W_{1}}\right)$

Where: $\mathrm{M}_{\mathrm{c}}$ is the moisture contents, $\mathrm{W}_{1}$ and $\mathrm{W}_{2}$ are the initial and final weights of the PCCS after drying at $105^{\circ} \mathrm{C}$

A known weight of the dried PCCS samples used (individually) for the determination of moisture content was placed in crucibles of known masses and transferred into a muffle furnace (Brother Furnace, XD 1220N). The muffle furnace was heated to $550^{\circ} \mathrm{C}$ for 2 hours and weighed, then reheated to $1200^{\circ} \mathrm{C}$ for 2 hours and weighed finally. The PCCS samples were allowed to cool in the desiccators to the room temperature, and the final weights of the crucibles and PCCS were determined. Volatile solid and ash contents of PCCS were computed as follows:

$$
\begin{aligned}
& V_{S}(\%)=100\left(\frac{W_{2}-W_{3}}{W_{2}}\right) \\
& A_{s h}(\%) \biguplus 0 \quad\left(\frac{W_{4}}{W_{1}}\right)
\end{aligned}
$$

Where: $W_{3}$ and $W_{4}$ is the final weight of PCCS after 2 hours in the muffle furnace at 550 and $1200^{\circ} \mathrm{C}, \mathrm{A}_{\text {sh }}$ and $\mathrm{V}_{\mathrm{S}}$ are the ash and volatile solid contents of the PCCS.

A 5 gram each of the samples were soaked in 300 $\mathrm{mL}$ of distilled water and $300 \mathrm{~mL}$ of $0.25 \mathrm{M}$ of $\mathrm{HCl}$ individually for 24 hours. The PCCS samples were filtered using pre-dried and weighed filter papers (number 1). The PCCS samples and the filter papers were dried in the oven at $105^{\circ} \mathrm{C}$ for 24 hours and allowed to cool in desiccators to the room temperature, and the final weights of the samples were determined. The water $\left(\mathrm{W}_{\mathrm{s}}\right)$ and acid solubilities $\left(A_{s}\right)$ of PCCS were computed as follows (Fehintola et al., 2015):

$$
W_{S}(\%)=100\left(\frac{W_{2}-W_{4}}{W_{2}}\right)
$$


$A_{S}(\%)=100\left(\frac{W_{2}-W_{5}}{W_{2}}\right)$

Where: $\mathrm{W}_{\mathrm{S}}$ is the water solubility of PCCS, $\mathrm{A}_{\mathrm{S}}$ is the acid solubility of PCCS, $\mathrm{W}_{4}$ and $\mathrm{W}_{5}$ are the dry weight of the PCCS after soaking in the distilled water and the $0.25 \mathrm{M}$ of $\mathrm{HCl}$ acid for 24 hours respectively.

A $2.0 \mathrm{~g}$ of the PCCS was digested using trioxonitrate $(\mathrm{V})$ acid digestion method as described in Standard Methods for Water and Wastewater Analysis (APHA, 2012, van Loosdrecht et al., 2016). The chemical properties of the PCCS were determined using standard methods (APHA, 2012) and the total metal concentrations $\left(M_{c c}\right)$ were determined using spectrophotometry method. Metal concentrations in the PCCS were computed as follows:

$q_{t}=\left(\frac{\left(C_{0}-C_{t}\right)}{M}\right) V$

Where: $\mathrm{B}$ is the dilution factor, $\mathrm{A}$ is the concentration of the metals $(\mathrm{mg} / \mathrm{L})$ in the PCCS obtained from the reading and $\mathrm{M}_{\mathrm{cc}}$ is the actual concentration of the metal.

Working solutions of $\mathrm{Pb}^{2+}$ were regularly prepared from the stock solution. In order to ascertain the adsorptions kinetics, known quantities of PCCS were added to a known volume $(300 \mathrm{ml})$ of a solution containing $19.47 \mathrm{mg} / \mathrm{L} \mathrm{Pb}^{2+}$ solution, stirred for 3 minutes and allowed to settle. The supernatants from the treatment process were filtered through a filter paper at an interval of 1 hour for 8 hours, and the filtrates were analyzed for $\mathrm{Pb}^{2+}$ concentration. For adsorptive rates of natural waters and raw water samples were collected from selected surface water in Ile-Ife. $\mathrm{Pb}^{2+}$ concentration the natural and raw water samples were determined. The natural and raw water samples (the water samples) were subjected to a similar treatment as for the synthetic $\mathrm{Pb}^{2+}$ solutions. The amount of solute removed (adsorbed) was computed using equation (7). The percentage of $\mathrm{Pb}^{2+}$ removed $\left(\mathrm{R}_{\mathrm{t}} \%\right)$ from the solution was calculated using equation (8) as follows:

$q_{t}=\left(\frac{\left(C_{0}-C_{t}\right)}{M}\right) V$
$R_{t}(\%)=100\left(\frac{\left(C_{0}-C_{t}\right)}{C_{0}}\right)$

Where: $\mathrm{q}_{\mathrm{t}}$ is the adsorption capacity at time $\mathrm{t}$ $(\mathrm{mg} / \mathrm{g}), \mathrm{C}_{0}$ is the initial concentration of lead in the solution $(\mathrm{mg} / \mathrm{L}), \mathrm{C}_{\mathrm{t}}$ is the concentration of lead in the solution at time $\mathrm{t}(\mathrm{mg} / \mathrm{L})$, and $R_{t}$ is the percentage of the pollutant adsorbed $(\%)$.

Effects of $\mathrm{pH}$ on the removal of $\mathrm{Pb}^{2+}$ from synthetic $\mathrm{Pb}^{2+}$ solution was investigated using PCCS of particle size $300-212 \mathrm{~m}\left(\right.$ PCCS $_{1}$ ) at different $\mathrm{pH}$ values (the $\mathrm{pH}$ of the solutions were controlled with either $0.01 \mathrm{M} \mathrm{HCl}$ or $\mathrm{NaOH}$ ), at an initial lead concentration of $0.64 \mathrm{mg} / \mathrm{L}$. $\mathrm{pH}$ of these solutions were determied using $\mathrm{pH}$ meter(Jenway 6051). The influence of adsorbent (PCCS) particle size on the $\mathrm{Pb}^{2+}$ removal from solution through batch adsorption processes was investigated using various particle sizes of PCCS $\left(\mathrm{PCCS}_{1}, \mathrm{PCCS}_{2}, \mathrm{PCCS}_{3}\right.$ and $\left.\mathrm{PCCS}_{4}\right)$ at $\mathrm{pH} 7.2$ and at an initial $\mathrm{Pb}^{2+}$ concentration of $0.64 \mathrm{mg} / \mathrm{L}$. The effect of initial concentrations on the adsorptive rate of lead ion using batch adsorption experiments was investigated at initial concentrations between $0.13 \mathrm{mg} / \mathrm{L}$ and $19.47 \mathrm{mg}$ / L. at particle size $75 \mathrm{~m}\left(\mathrm{PCCS}_{1}\right)$ and $\mathrm{pH}$ 7.2. The laboratory analyses of $\mathrm{pH}$ and $\mathrm{Pb}^{2+}$ concentrations in both synthetic and natural water used were conducted as specified in APHA (2012, van Loosdrecht et al., 2016) using $\mathrm{pH}$ meter (Jenway 6051) and spectrophotometer (Jenway 7315) method for $\mathrm{Pb}^{2+}$ concentrations. The adsorption kinetics of $\mathrm{Pb}^{2+}$ onto PCCS was analyzed using a pseudo second-order, Elovich, and intra-particle diffusion kinetic models through the use of Microsoft Excel Solver (MES), graphical and least square methods. Microsoft Excel Solver was used for the determination of the adsorption kinetics constants. The methods were evaluated statistically using Akaike Information Criterion, (AIC), Schwartz Criterion (SC), coefficient of Determination (CD) and Model of Selection Criterion (MSC). Expected concentrations were used as reference data. Procedures employed in the computations of model constants using Microsoft Excel Solver (MES) are as follows (Oke et al., 2017):

a) Microsoft Excel Solver was added in on the toolbar of Microsoft Excel; 
b) Target (limit) value of the iteration was set for the software based on square of difference as

$$
\sum_{i=1}^{n}\left(q_{t}-a+b X\right)^{2}
$$

$$
a=\left(\frac{\sum_{i=1}^{n} Y_{i}-b \sum_{i=1}^{n} X_{i}}{n}\right)
$$

c) Changing cells of the iterations were selected, number of iterations, degree of accuracy and maximum time for the iteration were set for the software to meet the target; and

d) The iteration started through Microsoft Excel Solver (Figure 1).

More on MES can be found in literature (Oke et al., 2016; 2017, Barati, 2013; Tay et al., 2014; Hui et al., 2018). In the utilization of least square method, equations used are as follows:

$$
\begin{aligned}
& Y=a+b X \\
& \sum_{i=1}^{n} Y_{i}=a n+b \sum_{i=1}^{n} X_{i} \\
& \sum_{i=1}^{n} X_{i} Y_{i}=a \sum_{i=1}^{n} X_{i}+b \sum_{i=1}^{n} X_{i}^{2}
\end{aligned}
$$

Using equations (11) and (12), $\mathrm{a}$ and $\mathrm{b}$ are determined as follows:

$$
b=\left(\frac{\sum_{i=1}^{n} X_{i} \sum_{i=1}^{n} Y_{i}-n \sum_{i=1}^{n} X_{i} Y_{i}}{\sum_{i=1}^{n} X_{i} \sum_{i=1}^{n} X_{i}-n \sum_{i=1}^{n} X_{i}^{2}}\right)
$$

Linear transformation of the second-order pseudo adsorption kinetic equation is expressed as shown in equation (15):

$$
\left(\frac{t}{q_{t}}\right)=\frac{1}{h}+\frac{1}{q_{e}} t
$$

Where: $\mathrm{q}_{\mathrm{e}}$ is the equilibrium solid phase concentration of sorbate $(\mathrm{mg} / \mathrm{mg})$, $t$ is the time, $k_{2}$ is the rate constant of second-order pseudo adsorption. Assuming the $h(\mathrm{mg} / \mathrm{g} \cdot \mathrm{h})$ is equal to $k_{2}(q)^{2}$

Erhan et al. (2004), Oke et al. (2008), Ismail et al. (2009) simplifies Elovich equation as follows:

$$
q_{t}=\frac{1}{\beta} \log _{e}(\alpha \beta)+\frac{1}{\beta} \log _{e}(t)
$$

Where: $\beta$ is the desorption constant during any experiment and is the initial adsorption rate

The intraparticle diffusion model is based on the theory proposed by Weber and Morris (1963). It was tested to identify the diffusion mechanism. It is an empirical functional relationship and is common to the most adsorption processes. The theory states that the uptake varies proportionally with $\mathrm{t}^{0.5}$ rather than with the contact time $\mathrm{t}$. 


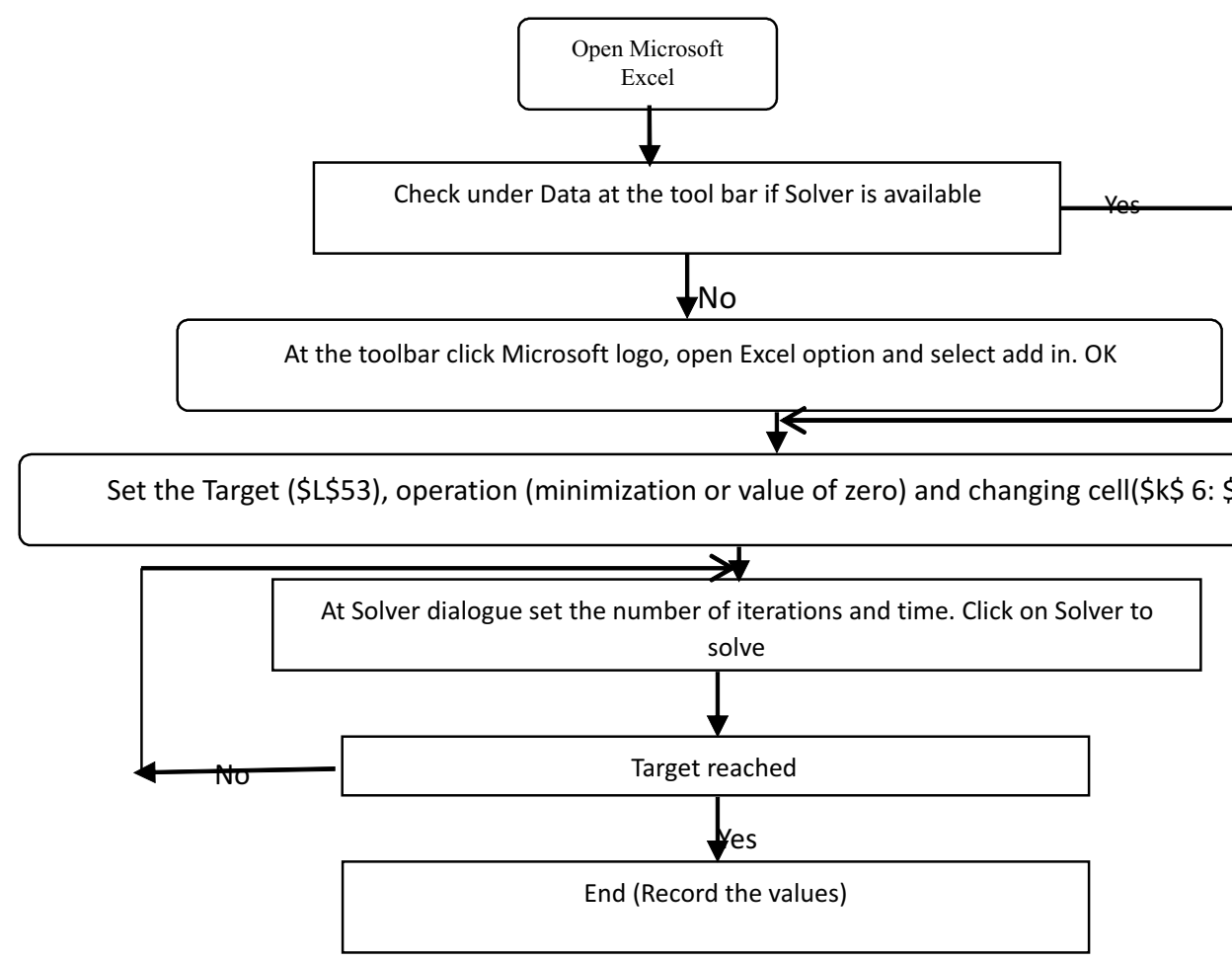

Figure 1: Procedure for using Microsoft Excel Solver in the computation of adsorption kinetics

According to this theory the equation can be expressed as follows (Edson et al., 2011):

$R=k_{p}(t)^{0.5}+I$

Where: $\mathrm{R}$ is the percentage of the pollutant adsorbed (\%), ' $t$ ' is the time, $k_{p}$ is the intraparticle diffusion rate constant $\left(/ \mathrm{h}^{0.5}\right)$ and $\mathrm{I}$ is a constant that describe the thickness of the boundary layer.

The Model of Selection Criterion (MSC) is interpreted as the proportion of expected chloride concentration and observed chloride concentrations variation that can be explained by the obtained chloride concentrations. Higher value of MSC indicates higher accuracy, validity and the good of fit of MSC. MSC method was computed using equation (18) as follows:

$$
M S C=\ln \frac{\sum_{i=1}^{n}\left(Y_{o b s i}-\bar{Y}_{o b s}\right)^{2}}{\sum_{i=1}^{n}\left(Y_{o b s i}-Y_{c a l i}\right)^{2}}-\frac{2 p}{n}
$$

where, $\mathrm{Y}_{\mathrm{obsi}}$ is the observed concentration; obs $\mathrm{Y}$ is the average of observed concentration; $p$ is the total number of fixed parameters to be estimated in the equation; $\mathrm{n}$ is the total number of concentration, and $Y_{\text {cali }}$ is the expected concentration.

The AIC was derived from the Information Criterion of Akaike (1976). It allows a direct comparison among models with a different number of parameters. The AIC presents the information on a given set of parameter estimates by relating the coefficient of determination to the number of parameters. The AIC values were computed using equation (19) as follows:

AIC $=n\left(\ln \sum_{i=1}^{n}\left(Y_{\text {obsi }}-Y_{\text {cali }}\right)^{2}\right)+2 p$

The Schwartz Criterion (SC) is defined by the formula in equation (20). SC was computed as follows:

$S C=n \ln \left(\sum_{i=1}^{n}\left(Y_{\text {obsi }}-Y_{\text {cali }}\right)^{2}\right)+p \ln (n)$

The more appropriate model is the one with the smaller SC value. Coefficient of determination (CD) can be interpreted as the proportion of expected data variation that can be explained by the obtained data. Higher values of CD indicate higher accuracy, validity and good fitness of the method. CD can be expressed as follows: 


$$
C D=\frac{\sum_{i=1}^{n}\left(Y_{\text {obsi }}-\overline{Y_{\text {cali }}}\right)^{2}-\sum_{i=1}^{n}\left(Y_{\text {obsi }}-Y_{\text {cali }}\right)^{2}}{\sum_{i=1}^{n}\left(Y_{\text {obsi }}-\overline{Y_{\text {cali }}}\right)^{2}}
$$

\section{RESULTS AND DISCUSSION}

The study revealed that that moisture content of the PCCS was $7.29 \%$, volatile solid at $550^{\circ} \mathrm{C}$ was $96.88 \%$ ( $96.63 \%$ based on the dried weight), and volatile solids at $1200^{\circ} \mathrm{C}$ was $99.44 \%(99.44 \%$ based on the dried weight). Ash contents of the PCCS were $3.13 \%(3.37 \%$ based on the dried weight), and $0.52 \%$ (0.56\% based on the dried weight) at $550^{\circ} \mathrm{C}$ and $1200^{\circ} \mathrm{C}$ respectively. Ogunjobi and Labunmi (2013) stated that yellow corncobs contained $9.80 \%$ ash content and 3.81 $\%$ moisture, while white corn cobs had $9.77 \%$ ash and $6.43 \%$ moisture contents. These results revealed that composition of corncobs is a function of the type of corncobs and locations. Results of water and acid solubilities were $4.53 \%$ (5.42\% of dried weight) and $13.00 \%$ (13.61\% of dried weight) respectively. Mineral composition of the PCCS indicated that one gram of PCCS contained $131.00 \mathrm{mg}$ of $\mathrm{Fe}$ as $\mathrm{Fe}^{2+}$ per gram of PCCS $(13.10 \%), 1.70 \mathrm{mg}$ calcium as $\mathrm{Ca}^{2+}(0.17 \%)$ and $0.010 \mathrm{mg} \mathrm{Al}$ as $\mathrm{Al}^{3+}$ (0.001\%). Zinc and Nickel contents were $0.01 \mathrm{mg} / \mathrm{g}$ each with neither lead ion nor cadmium ion present. Wanitwattanarumlug et al.(2012) reported that corn cob contained Cellulose $41.27 \%$, Hemicellulose $46.00 \%$ and Lignin $7.40 \%$. Okoronkwo et al. (2016) reported that corncobs ash contains $47.78 \% \mathrm{SiO}_{3}, 9.40 \% \mathrm{Al}_{2} \mathrm{O}_{3}, 8.31 \%$ $\mathrm{Fe}_{2} \mathrm{O}_{3}, 16.70 \% \mathrm{CaO}, 7.80 \% \mathrm{MgO}, 2.70 \% \mathrm{Mn}_{2} \mathrm{O}_{3}$, $5.42 \% \mathrm{~K}_{2} \mathrm{O}$ and $1.89 \% \mathrm{Na}_{2} \mathrm{O}$. These results indicate that PCCS ash was made up alkali metals (as $\mathrm{K}_{2} \mathrm{O}$ and $\mathrm{Na}_{2} \mathrm{O}$ ), alkali earth metals, other metals and silicates. It has been reported that some salts (calcium, iron and aluminum salts) undergo displacement reaction in aqueous medium as follows:

$$
\begin{aligned}
& \mathrm{Al}^{3+}+3 \mathrm{H}_{2} \mathrm{O} \rightarrow \frac{3}{2} \mathrm{H}_{2}+\mathrm{Al}(\mathrm{OH})_{3}(21 \mathrm{a}) \\
& \mathrm{Al}^{3+}+2 \mathrm{H}_{2} \mathrm{O} \rightarrow \frac{3}{2} \mathrm{H}_{2}+\mathrm{AlO}(\mathrm{OH})(21 \mathrm{~b}) \\
& \mathrm{Al}^{3+}+\frac{3}{2} \mathrm{H}_{2} \mathrm{O} \rightarrow \frac{3}{2} \mathrm{H}_{2}+\frac{1}{2} \mathrm{Al}_{2}(\mathrm{O})_{3}(21 \mathrm{c}) \\
& \mathrm{Fe}^{2+}+2 \mathrm{H}_{2} \mathrm{O} \rightarrow \mathrm{H}_{2}+\mathrm{Fe}(\mathrm{OH})_{2} \quad(21 \mathrm{~d})
\end{aligned}
$$

$$
\begin{aligned}
& \mathrm{Ca}^{2+}+2 \mathrm{H}_{2} \mathrm{O} \rightarrow \mathrm{H}_{2}+\mathrm{Ca}(\mathrm{OH})_{2} \quad(21 \mathrm{e}) \\
& \mathrm{Mg}^{2+}+2 \mathrm{H}_{2} \mathrm{O} \rightarrow \mathrm{H}_{2}+\mathrm{Mg}(\mathrm{OH})_{2}(21 \mathrm{f}) \\
& \mathrm{Mn}^{2+}+2 \mathrm{H}_{2} \mathrm{O} \rightarrow \mathrm{H}_{2}+\mathrm{Mn}(\mathrm{OH})_{2}(21 \mathrm{~g}) \\
& 2 \mathrm{~K}^{+}+2 \mathrm{H}_{2} \mathrm{O} \rightarrow \mathrm{H}_{2}+2 \mathrm{~K}(\mathrm{OH})(21 \mathrm{~h}) \\
& 2 \mathrm{Na}^{+}+2 \mathrm{H}_{2} \mathrm{O} \rightarrow \mathrm{H}_{2}+2 \mathrm{Na}(\mathrm{OH})(21 \mathrm{i})
\end{aligned}
$$

The first reaction (21a) forms the aluminum hydroxide bayerite $\left(\mathrm{Al}(\mathrm{OH})_{3}\right)$ and hydrogen, the second reaction (21b) forms the aluminum hydroxide boehmite $(\mathrm{AlO}(\mathrm{OH}))$ and hydrogen, and the third reaction (21c) forms aluminum oxide and hydrogen. All these reactions are thermodynamically favorable from room temperature past the melting point of aluminum $\left(660^{\circ} \mathrm{C}\right)$. All are also highly exothermic. From room temperature to $280^{\circ} \mathrm{C}, \mathrm{Al}(\mathrm{OH})_{3}$ is the most stable product, while from $280-480^{\circ} \mathrm{C}, \mathrm{AlO}(\mathrm{OH})$ is most stable. Above $480{ }^{\circ} \mathrm{C}, \mathrm{Al}_{2} \mathrm{O}_{3}$ is the most stable product. This result shows that the PCCS underwent the reaction in equation (22) with lead ion, which can reduce the $\mathrm{pH}$ and the end product reacted with lead ion to precipitate the pollutant.

$$
\begin{aligned}
& \mathrm{Ca}(\mathrm{OH})_{2}+\mathrm{Pb}^{2+} \rightarrow \mathrm{Ca}^{2+}+\mathrm{Pb}(\mathrm{OH})_{2} \\
& \mathrm{Fe}(\mathrm{OH})_{2}+\mathrm{Pb}^{2+} \rightarrow \mathrm{Fe}^{2+}+\mathrm{Pb}(\mathrm{OH})_{2} \\
& \left.2 \mathrm{Al}(\mathrm{OH})_{3}+3 \mathrm{~Pb}^{2+} \rightarrow 2 \mathrm{~b}\right) \\
& \left.\mathrm{Mg}(\mathrm{OH})_{2}+\mathrm{Pb}^{2+}+3 \mathrm{~Pb}(\mathrm{OH})_{2} 22 \mathrm{c}\right) \\
& \mathrm{Mn}(\mathrm{OH})_{2}+\mathrm{Pb}^{2+}+\mathrm{Pb}(\mathrm{OH})_{2} \quad(22 \mathrm{~d}) \\
& 2 \mathrm{Na}(\mathrm{OH})+2 \mathrm{Mb}^{2+}+\mathrm{Pb}(\mathrm{OH})_{2} \quad(22 \mathrm{e})
\end{aligned}
$$

These equations revealed the reaction PCCS underwent with $\mathrm{Pb}^{2+}$, which reduced the $\mathrm{pH}$ of the treated solution and the end product reacted with $\mathrm{Pb}^{2+}$ to precipitate the pollutant. Literature such as Wanitwattanarumlug et al.(2012), Amoko et al.(2015), Okoronkwo et al. (2016) and Arellano et al. (2016) show effects of selected factors and reagents on micrograph structure of the PCCS. These figures from literature (Wanitwattanarumlug et al,.2012, Amoko et al., 2015, Okoronkwo et al., 2016 and Arellano et al., 
2016) revealed that the potassium hydroxide pretreatment with microwave on corncobs was an effective technique for improving enzymatic hydrolysis accessibility. The optimum conditions for PCCS were found to be $2 \%$ of $\mathrm{KOH}$ at $120^{\circ} \mathrm{C}$ for a duration of 25 minutes which could increase in surface area by $45.67 \%$ and the cellulose crystallinity index of the material up to $57.28 \%$. Figure 2 presents the micrograph structures of the PCCS as obtained from Literature. These figures (SEM) revealed that there are pores on raw, modified and treated PCCS, which indicate that PCCS is a good adsorbent at various stages.

Figure 3 ( $a$ and $b$ ) presents adsorption kinetics of lead onto the adsorbent. From the figure it can be seen that adsorption of lead by the adsorbent increases with time. This observation agrees with the literature on adsorption of lead by various adsorbents. From the figure, it was evident that the adsorption processes of $\mathrm{Pb}^{2+}$ onto the adsorbent followed two steps. The first step was linear portion followed the boundary layer diffusion followed by another linear portion which represents the intra particle diffusion. This shows that the adsorption processes were not only by intraparticle diffusion but the film diffusion also played a role in the observed processes. Adsorption kinetics are important ingredients in environmental pollution control. In order to investigate in detail of the mechanism of adsorption rate for the adsorption of $\mathrm{Pb}^{2+}$ onto the adsorbents, the constants were determined using MES, graphical and least square methods for the pseudo second kinetic order, Elovich and intraparticle models. Table 1 shows the values of pseudo second order pseudo second order, Elovich and Intraparticle kinetics models. The pseudo second order kinetics model's parameters $\left(\mathrm{k}_{2}\right.$ and $\mathrm{q}_{\mathrm{e}}$ ) for each of the methods. $\mathrm{k}_{2}$ and $\mathrm{q}_{\mathrm{e}}$ were in the range of 0.006 to 22.455 and 0.044 to $59.880,0.001$ to 18.153 and 0.091 to 59.880 , and 0.002 to 18.151 and 0.089 to 59.878 for graphical, least square and MES methods respectively. The lowest $\mathrm{k}_{2}$ (- 0.002) came from Microsoft Excel Solver method and the highest value of $\mathrm{k}_{2}$ came from least square and graphical methods. Also, the lowest $\mathrm{q}_{\mathrm{e}}(0.044)$ came from graphical method. The highest value of $\mathrm{q}_{\mathrm{e}}$ came from the Microsoft Excel Solver method. These results indicated that the values of $k_{2}$ and $q_{e}$ are functions of the adsorbates, adsorbents and methods used. In the case of Elovich and intrapaticle kinetics models, their constants follow the same pattern as pseudo second kinetics model. For intra-particle model, the values for $C$ revealed the idea on the thickness of the boundary layer. The values of $\mathrm{C}$ were found to be less than zero $(0)$ in almost all the cases (including raw water samples), which indicated that the mode of adsorption and transport are affected by more than one process.

Table 2 presents statistical evaluation of the three methods. The table revealed that the overall lowest AIC (-36.39), and the highest MSC (7.46) came from MES method. The next to MES method was least square method while graphical was the methods with the highest overall AIC and the lowest MSC. The observations indicate that the order of accuracy of the methods was in Microsoft Excel Solver $>$ Least Squared > Graphical method based on the value of MSC. Tables 3 to 7 present statistical evaluation of effects of the selected factors on the performance adsorption of lead ion onto PCCS. 


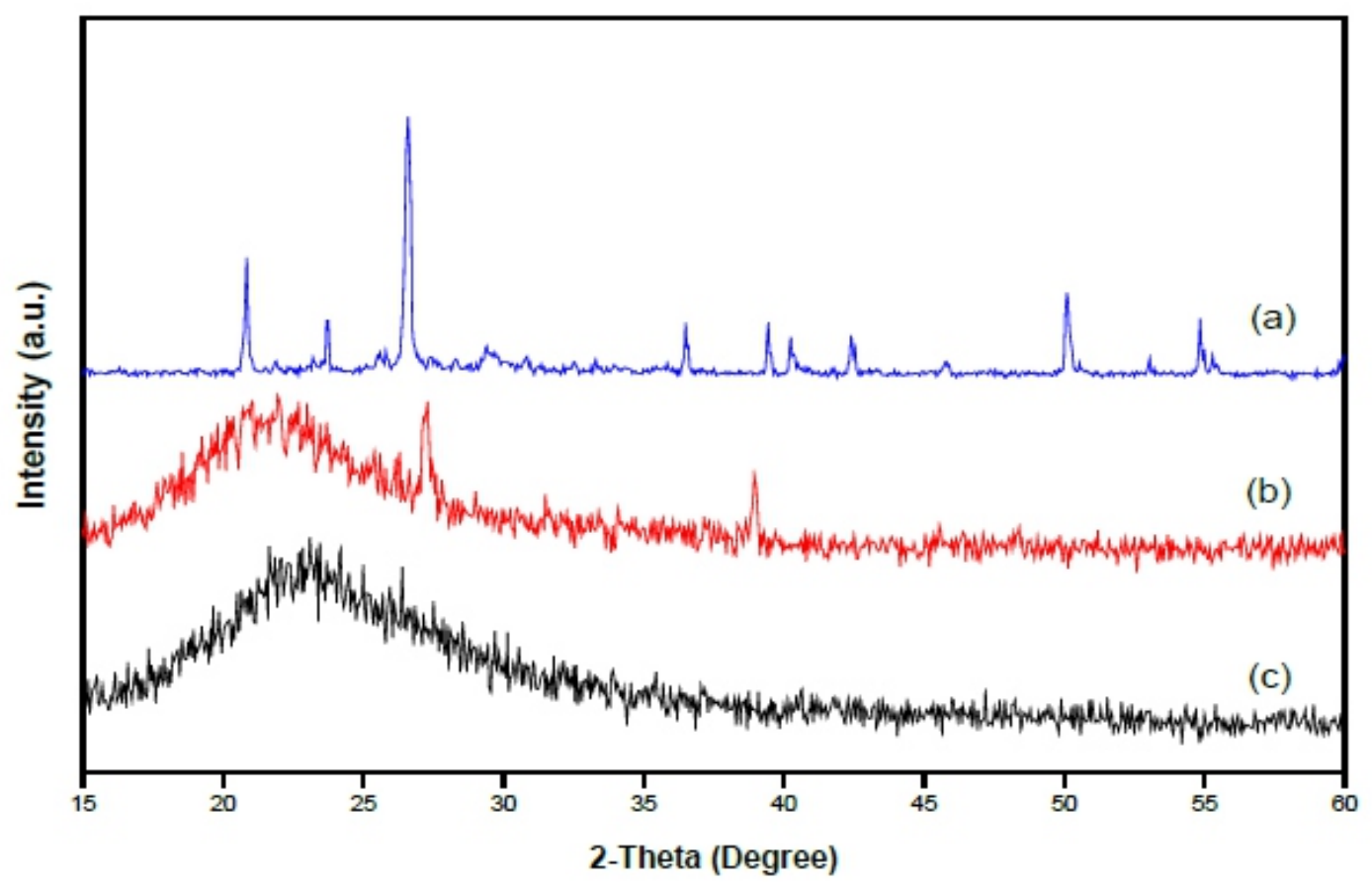

Figure 2a. XRD pattern of (a) Corn con ash; (b) extracted silica and (c) Nano silica (Source: Okoronkwo et al. 2016)

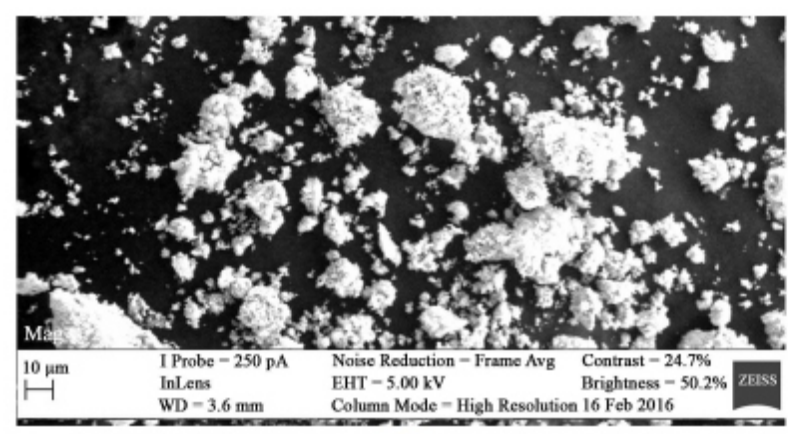

(a)

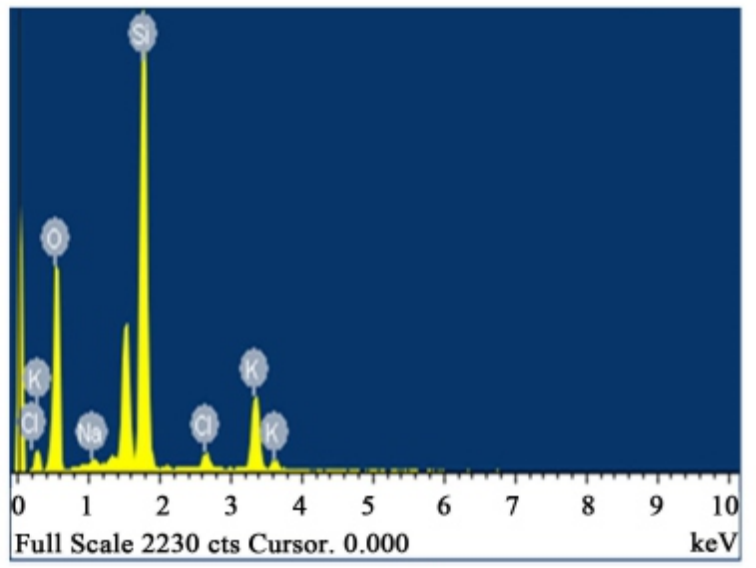

(b)

Figure 2b. SEM image of (a) Nano-structured silica and (b) EDS spectrum (Source: Okoronkwo et al. 2016) 


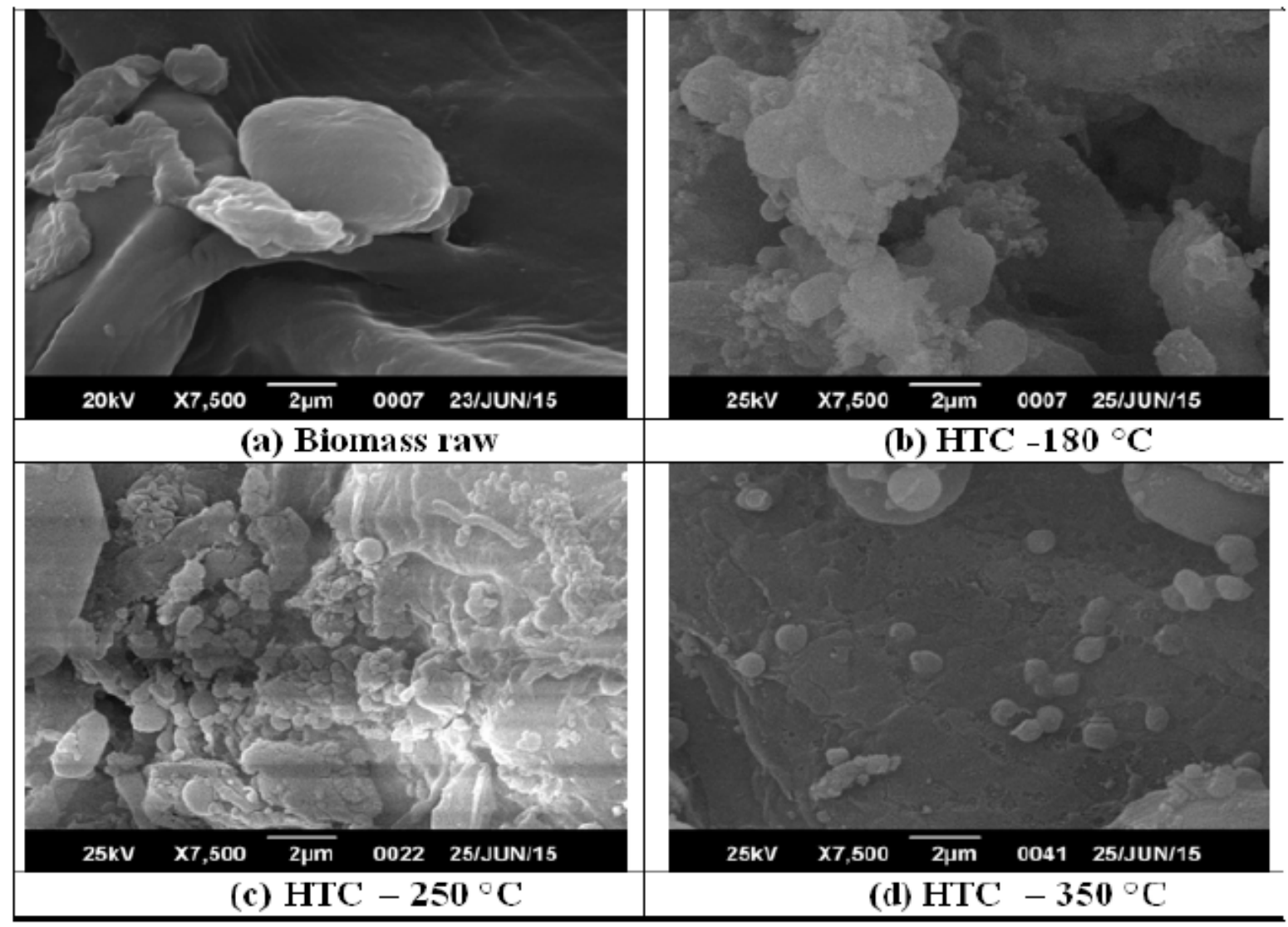

Figure 2c: Micrographs obtained for biomass (a) hydrothermal carbonization (HTC) products at, (b) $180{ }^{\circ} \mathrm{C}$, , (c) $250{ }^{\circ} \mathrm{C}$ and (d) $350{ }^{\circ} \mathrm{C}($ Source: Arellano et al. 2016)

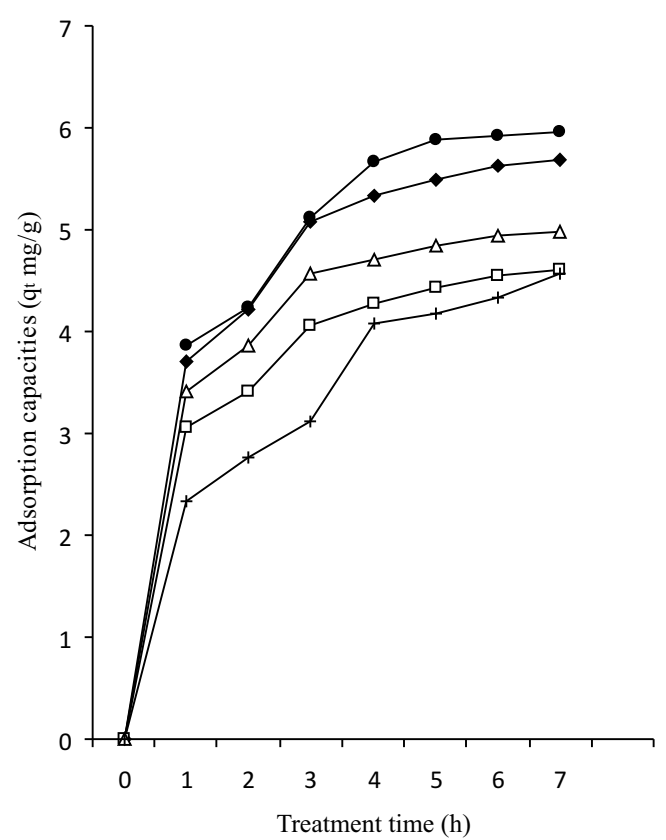

$\longrightarrow-212-150 \rightarrow \square-300-212-\triangle>75$
$\multimap-150-75 \longrightarrow<300$

(a)

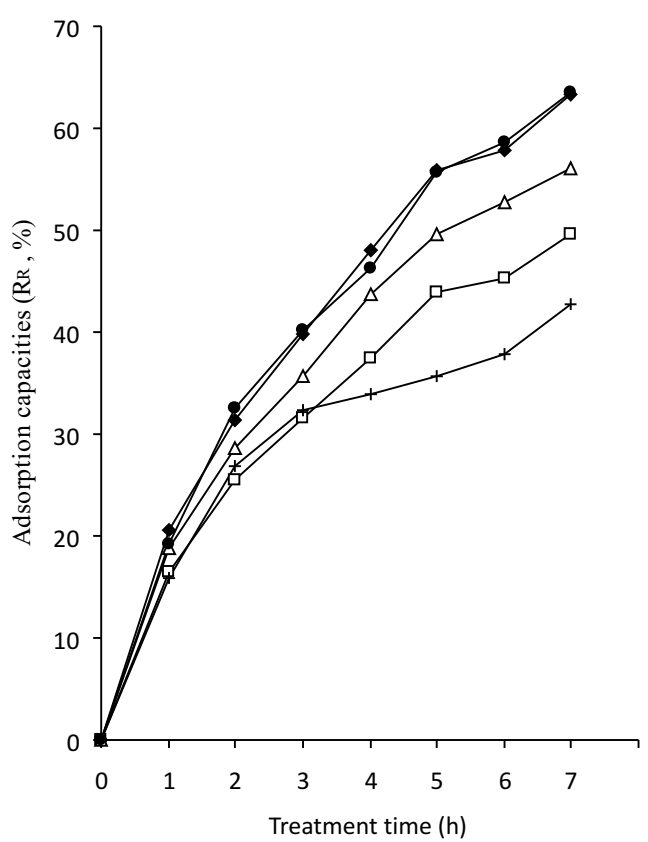

$\begin{array}{ll}\longrightarrow-0.13 \mathrm{mg} / \mathrm{L} & \longrightarrow-13 \mathrm{mg} / \mathrm{L} \longrightarrow 4.25 \mathrm{mg} / \mathrm{L} \\ \longrightarrow-0.25 \mathrm{mg} / \mathrm{L} \longrightarrow 19.47 \mathrm{mg} / \mathrm{L}\end{array}$

(b)

Figure 3: Adsorption capacities and kinetics of lead ion unto the PCCS at pH of 7.2 and at room temperature (a) Adsorption capacities $(\mathrm{mg} / \mathrm{g})$ at various particle sizes $\left(\mathrm{x} 10^{-6} \mathrm{~m}\right)$ with respect to time; (b) Adsorption capacities (\%) at various initial concentration of $\mathrm{Pb}^{2+}$ with respect to time 


\begin{tabular}{|c|c|c|c|c|c|c|c|c|c|c|c|c|c|c|c|}
\hline & א్ & : & 命 & $\stackrel{\infty}{m}$ & $\begin{array}{l}0 \\
\dot{b} \\
\dot{b}\end{array}$ & 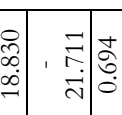 & $\begin{array}{l}\text { oे } \\
\text { : } \\
\dot{q}\end{array}$ & 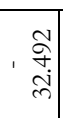 & $\begin{array}{l}\text { 学 } \\
\dot{f} \\
\end{array}$ & 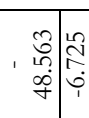 & $\begin{array}{l}\stackrel{0}{+} \\
\text { iे }\end{array}$ & 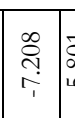 & & îj. & 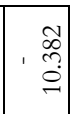 \\
\hline & $\stackrel{\infty}{\stackrel{\infty}{+}}$ & 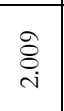 & $\begin{array}{l}n \\
\hat{b} \\
i\end{array}$ & స్ర & 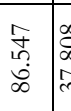 & 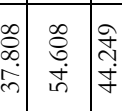 & 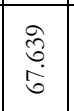 & 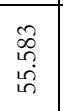 & ते & 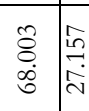 & 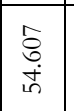 & & 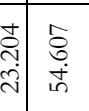 & $\begin{array}{l}\overrightarrow{\tilde{\sigma}} \\
\overrightarrow{\vec{\sigma}}\end{array}$ & $\begin{array}{l}\stackrel{8}{0} \\
\dot{i} \\
\text { ja }\end{array}$ \\
\hline & مَ & : & 占 & $\stackrel{\infty}{\infty}$ & 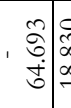 & 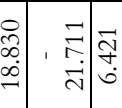 & $\begin{array}{l}\stackrel{9}{7} \\
\stackrel{1}{\dot{g}}\end{array}$ & 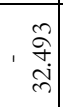 & 年 & 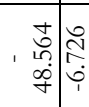 & 蚉 & 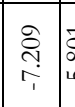 & & 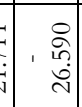 & 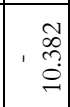 \\
\hline & $\stackrel{\infty}{\stackrel{\infty}{\stackrel{f}{\sim}}}$ & छे & 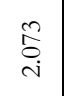 & $\widetilde{\delta}$ & 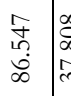 & 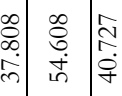 & \begin{tabular}{l} 
त్రి \\
\multirow{0}{0}{}
\end{tabular} & $\begin{array}{l}+ \\
\text { 足 } \\
\text { in } \\
\text { in }\end{array}$ & 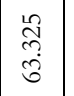 & 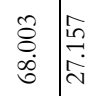 & \begin{tabular}{|l}
$\infty$ \\
\multirow{3}{0}{} \\
$\dot{+}$ \\
$\stackrel{1}{n}$
\end{tabular} & 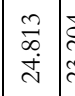 & 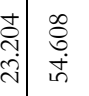 & $\begin{array}{l}\overrightarrow{\widetilde{\sigma}} \\
\vec{\sigma}\end{array}$ & 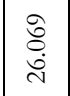 \\
\hline & 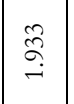 & $\stackrel{n}{\stackrel{n}{0}}$ & 会 & $\stackrel{\infty}{\infty}$ & 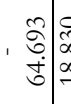 & 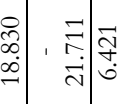 & , & 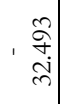 & $\begin{array}{l}\stackrel{n}{+} \\
\dot{f} \\
\dot{f}\end{array}$ & în & : & 공 & & i. & 总 \\
\hline & $\stackrel{\infty}{\stackrel{\infty}{\sim}}$ & $\widetilde{\widetilde{\gamma}}$ & $\stackrel{\tilde{S}}{\tilde{S}}$ & గ్ర & 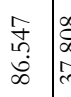 & 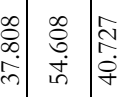 & $\mid$\begin{tabular}{l}
$\widehat{\widehat{b}}$ \\
\multirow{0}{0}{}
\end{tabular} & 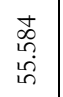 & $\begin{array}{l}\stackrel{1}{2} \\
\hat{3} \\
\text { రై }\end{array}$ & 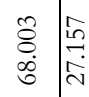 & \begin{tabular}{|l}
$\infty$ \\
o \\
$\stackrel{+}{\circ}$ \\
$\stackrel{1}{n}$
\end{tabular} & 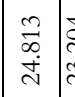 & & $\begin{array}{l}\overrightarrow{\vec{\alpha}} \\
\vec{\sigma}\end{array}$ & 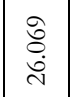 \\
\hline & 孟 & 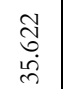 & 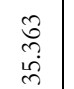 & $\bar{\sigma}$ & 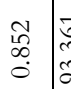 & 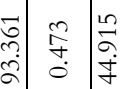 & \begin{tabular}{l}
$\stackrel{\Im}{0}$ \\
\multirow{f}{0}{}
\end{tabular} & 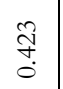 & $\mid \begin{array}{l}\infty \\
0 \\
0 \\
0\end{array}$ & & 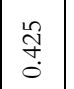 & 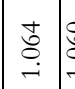 & 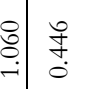 & ֻे & त్ \\
\hline & $\begin{array}{l} \\
\\
0 \\
0 \\
0\end{array}$ & \begin{tabular}{l|}
$\infty$ \\
$\vdots$ \\
0 \\
0
\end{tabular} & $\begin{array}{l}0 \\
0 \\
0 \\
0 \\
0\end{array}$ & $\stackrel{ᄋ}{\varrho}$ & 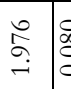 & 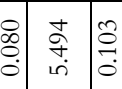 & \begin{tabular}{l}
\multirow{6}{*}{} \\
$\dot{+}$
\end{tabular} & 苛 & $\begin{array}{l}\hat{O} \\
\stackrel{0}{+} \\
\dot{+}\end{array}$ & 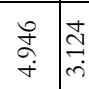 & 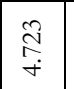 & 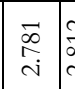 & 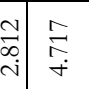 & @े & $\begin{array}{l}\vec{\sigma} \\
\dot{\sigma}\end{array}$ \\
\hline & $\begin{array}{l}\text { o } \\
\text { d̦ } \\
\text { d }\end{array}$ & 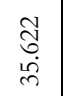 & 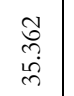 & 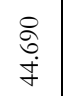 & 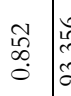 & 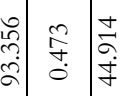 & $\begin{array}{l}\stackrel{\Re}{4} \\
\stackrel{+}{\sigma}\end{array}$ & ồ & 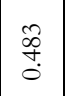 & 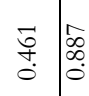 & 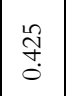 & 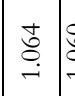 & \begin{tabular}{l|l} 
\\
\hdashline \\
\hdashline \\
\hdashline
\end{tabular} & 点 & $\begin{array}{l}\hat{\jmath} \\
\text { ठ }\end{array}$ \\
\hline & $\begin{array}{l}0 \\
0 \\
0 \\
0 \\
0\end{array}$ & $\begin{array}{l}\infty \\
\stackrel{\infty}{0} \\
0\end{array}$ & $\stackrel{\mathscr{D}}{0}$ & $\approx$ & 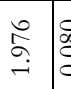 & 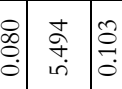 & 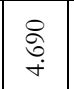 & ర్ర్ర & $\approx$ & 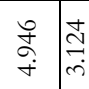 & 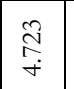 & 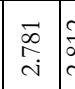 & 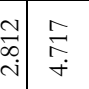 & 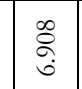 & $\begin{array}{l}\overrightarrow{\widehat{\delta}} \\
\stackrel{a}{\circ}\end{array}$ \\
\hline & 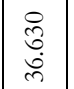 & $\begin{array}{l}n \\
\infty \\
i n \\
n \\
n\end{array}$ & ले & $\begin{array}{l}\text { fo } \\
\dot{f} \\
\dot{f}\end{array}$ & 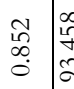 & 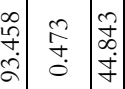 & \begin{tabular}{c} 
フे \\
\multirow{\sigma}{\delta}{}
\end{tabular} & $\stackrel{\vartheta}{\stackrel{\jmath}{0}}$ & $\mid \begin{array}{c}\infty \\
\infty \\
0 \\
0\end{array}$ & 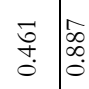 & 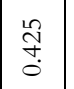 & 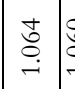 & \begin{tabular}{l|l}
$\stackrel{0}{0}$ & 0 \\
\hdashline & \multirow{2}{*}{} \\
\hdashline & 0 \\
\end{tabular} & ثิ & तิ \\
\hline & $\begin{array}{l}0 \\
\vdots \\
0 \\
0\end{array}$ & 央 & $\begin{array}{l}0 \\
\infty \\
0 \\
0\end{array}$ & 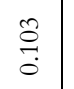 & 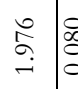 & 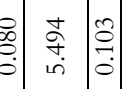 & $\begin{array}{l}\stackrel{0}{\circ} \\
\dot{+}\end{array}$ & 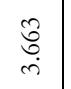 & $\begin{array}{l}\text { Oे } \\
\dot{+} \\
\dot{+}\end{array}$ & 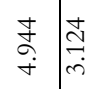 & 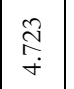 & 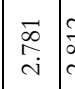 & 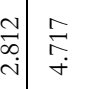 & $\begin{array}{l}0 \\
\grave{\delta} \\
\text { bे }\end{array}$ & $\begin{array}{l}\vec{\delta} \\
\dot{\sigma} \\
\dot{\sigma}\end{array}$ \\
\hline & $\begin{array}{l}\text { t } \\
\text { i } \\
\text { i }\end{array}$ & 年 & ণֶ & 3 & \begin{tabular}{l|l}
0 \\
0 \\
0
\end{tabular} & 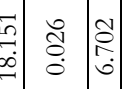 & $\begin{array}{l}\infty \\
\stackrel{8}{0} \\
0\end{array}$ & ठ̊. & 音 & \begin{tabular}{l|l}
$\infty$ & $\infty$ \\
$\stackrel{0}{0}$ & $\stackrel{0}{0}$ \\
$\stackrel{0}{0}$ & $\stackrel{0}{0}$
\end{tabular} & 足 & 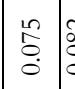 & 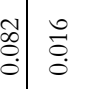 & $\stackrel{8}{\circ}$ & : \\
\hline & F & $\overrightarrow{\mathbb{A}}$ & $\stackrel{1}{\circ}$ & $\stackrel{\circ}{ }$ & 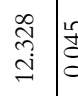 & 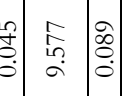 & $\begin{array}{l}\underset{I}{ \pm} \\
\underset{J}{ \pm}\end{array}$ & $\begin{array}{l}\infty \\
\infty \\
\infty \\
i \\
i\end{array}$ & 悉 & 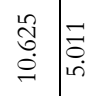 & $\begin{array}{l}\overrightarrow{\hat{\lambda}} \\
\dot{2}\end{array}$ & 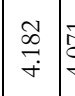 & 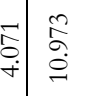 & 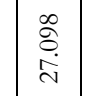 & ì \\
\hline & i & 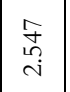 & $\begin{array}{l}\text { ț } \\
\stackrel{i}{i}\end{array}$ & 惑 & 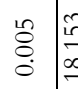 & 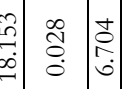 & $\stackrel{\circ}{\circ}$ & \& & 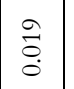 & $\begin{array}{c}\stackrel{0}{0} \\
\stackrel{0}{\circ} \\
\stackrel{0}{\circ}\end{array}$ & 吕 & 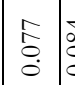 & 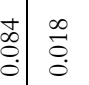 & 䒿 & $\begin{array}{l}\infty \\
\vdots \\
0\end{array}$ \\
\hline & ने & $\stackrel{\pi}{\tilde{H}}$ & ปี & $\bar{\AA}$ & 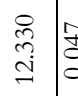 & 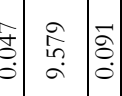 & $\begin{array}{l}\stackrel{ \pm}{ \pm} \\
\underset{ \pm}{ \pm}\end{array}$ & $\begin{array}{l}\infty \\
\infty \\
\infty \\
i\end{array}$ & 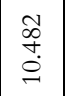 & \begin{tabular}{l|l}
$\hat{G}$ & $\stackrel{m}{0}$ \\
$\stackrel{0}{\leftrightarrows}$ & in
\end{tabular} & $\begin{array}{l}2 \\
\hat{\alpha} \\
\stackrel{g}{a}\end{array}$ & 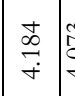 & \begin{tabular}{l|l}
$\stackrel{n}{n}$ & $\stackrel{n}{5}$ \\
$\stackrel{5}{+}$ & $\stackrel{0}{\subseteq}$
\end{tabular} & 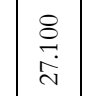 & 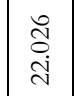 \\
\hline & 递 & ळे & $\stackrel{n}{\underset{7}{f}}$ & శ్ర్ & 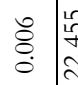 & 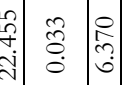 & $\stackrel{\circ}{\circ}$ & : & $\mid \begin{array}{l}\hat{\sigma} \\
\dot{0}\end{array}$ & 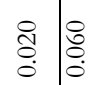 & 号 & 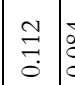 & 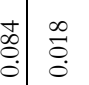 & 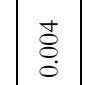 & $\begin{array}{l}\infty \\
0 \\
0\end{array}$ \\
\hline & $\stackrel{2}{\circ}$ & $\stackrel{n}{\circ}$ & $\stackrel{m}{0}$ & ठ̊ & \begin{tabular}{l|l}
$\vec{p}$ \\
$\stackrel{g}{g}$ \\
$\Rightarrow$
\end{tabular} & 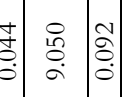 & $\begin{array}{l}\stackrel{ \pm}{ \pm} \\
\underset{ \pm}{ \pm}\end{array}$ & 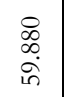 & $\mid$ & 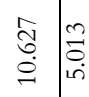 & $\mid \begin{array}{c}\alpha \\
\hat{a} \\
\dot{g}\end{array}$ & 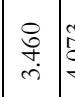 & 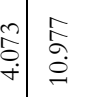 & 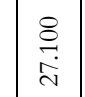 & $\begin{array}{l}\text { त् } \\
\text { तె }\end{array}$ \\
\hline 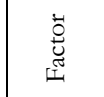 & . & $\mid \begin{array}{l}n \\
0 \\
0 \\
0 \\
0\end{array}$ & $n$ & $\overrightarrow{b 0}$ & ప. & 实 & & & & $\underline{a}$ & $\underset{f}{f}$ & 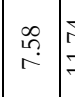 & & & $\exists$ \\
\hline 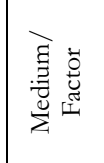 & & & & & & 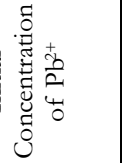 & & . & & & 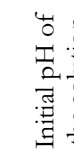 & & & $\begin{array}{ll}4 \\
0\end{array}$ & \\
\hline
\end{tabular}




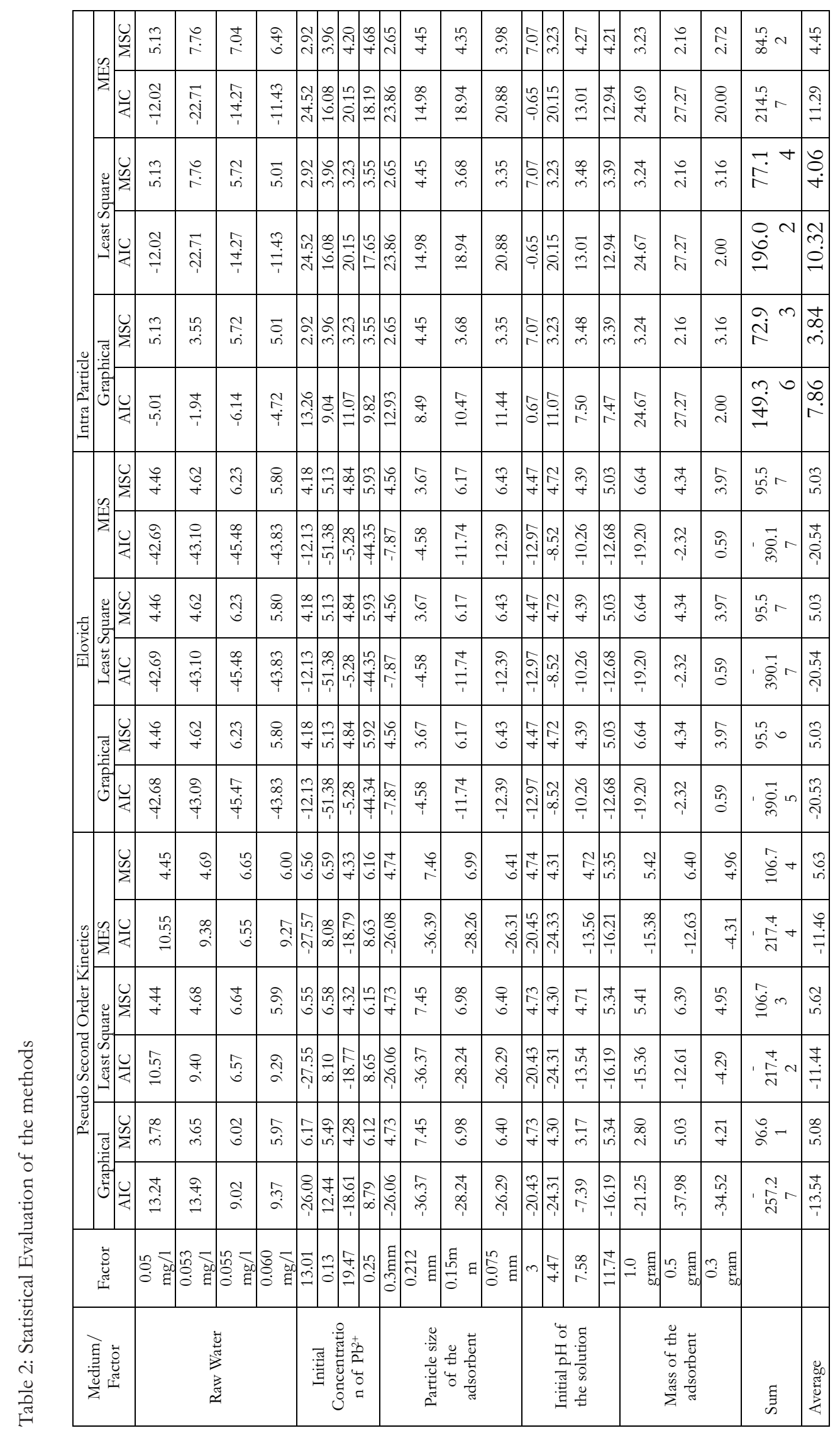


Adekunbi et al.: Evaluation of Microsoft Excel Solver as a Tool

Table 3: Result of statistical analysis of effect of adsorbent mass and adsorption period on performance

\begin{tabular}{ccccccc}
\hline Source of Variation & $\begin{array}{c}\text { Sum of } \\
\text { Squares }\end{array}$ & Degree of freedom & $\begin{array}{c}\text { Mean } \\
\text { Square }\end{array}$ & F-value & P-value & Fcrit \\
\hline Between Mass of Adsorbent & 0.238 & 2 & 0.119 & 38.100 & 0.0004 & 5.143 \\
Adsorption Period & 0.091 & 3 & 0.030 & 9.696 & 0.0102 & 4.757 \\
Error & 0.019 & 6 & 0.003 & & & \\
Total & 0.347 & 11 & & & & \\
\hline
\end{tabular}

Table 4: Result of statistical analysis of effect of $\mathrm{pH}$ and adsorption period on performance

\begin{tabular}{ccccccc}
\hline Source of Variation & $\begin{array}{c}\text { Sum of } \\
\text { Squares }\end{array}$ & $\begin{array}{c}\text { Degree of } \\
\text { freedom }\end{array}$ & $\begin{array}{c}\text { Mean } \\
\text { Square }\end{array}$ & F-value & P-value & Fcrit \\
\hline Within $\mathrm{pH}$ & 1.561 & 3 & 0.520 & 26.949 & 0.00001 & 3.490 \\
$\mathrm{pH}$ and Time & 1.059 & 4 & 0.265 & 13.706 & 0.00020 & 3.259 \\
Error & 0.232 & 12 & 0.019 & & & \\
Total & 2.852 & 19 & & & & \\
\hline
\end{tabular}

Table 5: Result of statistical analysis of effect of particle size of PCCS and adsorption period on performance

\begin{tabular}{ccccccc}
\hline Source of Variation & $\begin{array}{c}\text { Sum of } \\
\text { Squares }\end{array}$ & $\begin{array}{c}\text { Degree of } \\
\text { freedom }\end{array}$ & $\begin{array}{c}\text { Mean } \\
\text { Square }\end{array}$ & F-value & P-value & Fcrit \\
\hline Within Initial Concentration of Lead & 28421.151 & 3 & 9473.717 & 32.460 & $4.867 \times 10^{-06}$ & 3.490 \\
Initial concentration and Adsorption Time & 2854.696 & 4 & 713.674 & 2.445 & 0.1033 & 3.259 \\
Error & 3502.263 & 12 & 291.855 & & & \\
Total & 34778.109 & 19 & & & & \\
\hline
\end{tabular}

Table 6: Result of statistical analysis of effect of initial concentration of lead ion and adsorption period on performance

\begin{tabular}{ccccccc}
\hline Source of Variation & $\begin{array}{c}\text { Sum of } \\
\text { Squares }\end{array}$ & $\begin{array}{c}\text { Degree of } \\
\text { freedom }\end{array}$ & $\begin{array}{c}\text { Mean } \\
\text { Square }\end{array}$ & F-value & P-value & Fcrit \\
\hline Within Particle size of PCC & 0.075 & 3 & 0.025 & 10.262 & 0.0029 & 3.863 \\
Particle size of PCCS and & 0.097 & 3 & 0.032 & 13.157 & 0.0012 & 3.863 \\
Adsorption time & 0.022 & 9 & 0.002 & & & \\
Error & 0.194 & 15 & & & & \\
Total & & &
\end{tabular}

Table 7 Result of statistical analysis of applicability of adsorption performance on water quality

\begin{tabular}{ccccccc}
\hline Source of Variation & $\begin{array}{c}\text { Sum of } \\
\text { Squares }\end{array}$ & $\begin{array}{c}\text { Degree of } \\
\text { freedom }\end{array}$ & $\begin{array}{c}\text { Mean } \\
\text { Square }\end{array}$ & F-value & P-value & Fcrit \\
\hline Raw Water Samples & 30.465 & 3 & 10.155 & 2.839 & 0.0827 & 3.490 \\
Raw water and Adsorption Time & 3804.649 & 4 & 951.162 & 265.904 & $1.337 \times 10-11$ & 3.259 \\
Error & 42.925 & 12 & 3.577 & & & \\
Total & 3878.040 & 19 & & & & \\
\hline
\end{tabular}

Statistical evaluations of effects of the factors on performance of adsorption using analysis of variance (ANOVA) revealed that mass of adsorbent $\left(\mathrm{F}_{2,6}=38.10, \mathrm{p}=0.0004\right)$, adsorption period (treatment time, $\mathrm{F}_{2,6}=38.10, \mathrm{p}=0.0004$ ),
$\mathrm{pH}\left(\mathrm{F}_{3,126}=26.949, \mathrm{p}=0.0004\right)$, interaction of $\mathrm{pH}$ and treatment time $\left(\mathrm{F}_{4,6}=13.706, \mathrm{p}=0.0002\right)$, interaction of particle size and treatment time $\left(\mathrm{F}_{3,9}\right.$ $=13.157, \mathrm{p}=0.0012)$ and initial concentration $\left(\mathrm{F}_{3,12}=32.460, \mathrm{p}=0.0029\right)$ were significant factors 
and interaction that had effects on performance of $\mathrm{Pb}^{2+}$ adsorption onto PCCS in synthetic wastewaters at $95 \%$ confidence level. On typical raw water, the water sample (concentration of the pollutant, $\mathrm{pH}$, temperature and other factors, $\mathrm{F}_{3,12}$ $=2.839, \mathrm{p}=0.0827)$, interaction of raw water and adsorption time $\left(\mathrm{F}_{4,12}=265.904, \mathrm{p}=1.337 \times 10^{-11}\right)$ were significant factor and interaction that influence adsorption of the pollutant at $90 \%$ confidence level.

\section{CONCLUSION}

This study investigated adsorption capacities of $\mathrm{Pb}^{2+}$ onto absorbents, and utilization of graphical, least square and MES methods for pseudo second order, Elovich and Intraparticle kinetics models as well as evaluation of the methods statistically. The study concluded that

a. the adsorption processes of $\mathrm{Pb}^{2+}$ onto the adsorbents followed two steps,

b. mode of adsorption and transport are affected by more than one process,

c. the order of accuracy of the methods was in Microsoft Excel Solver $>$ Least Squared $>$ Graphical method based on the value of MSC and AIC,

d. mass of adsorbent $\left(\mathrm{F}_{2,6}=38.10, \mathrm{p}=\right.$ 0.0004), adsorption period (treatment time, $\left.\mathrm{F}_{2,6}=38.10, \mathrm{p}=0.0004\right), \mathrm{pH}\left(\mathrm{F}_{3,126}=\right.$ 26.949, $\mathrm{p}=0.0004)$, interaction of $\mathrm{pH}$ and treatment time $\left(\mathrm{F}_{4,6}=13.706, \mathrm{p}=\right.$ $0.0002)$, interaction of particle size and treatment time $\left(\mathrm{F}_{3,9}=13.157, \mathrm{p}=0.0012\right)$ and initial concentration $\left(\mathrm{F}_{3,12}=32.460, \mathrm{p}\right.$ $=0.0029)$ were significant factors that had effects on performance of $\mathrm{Pb}^{2+}$ adsorption onto PCCS in synthetic wastewaters at $95 \%$ confidence level, and

e. the water sample (concentration of the pollutant, $\mathrm{pH}$, temperature and other factors, $\mathrm{F}_{3,12}=2.839, \mathrm{p}=0.0827$ ), interaction of raw water and adsorption time $\left(\mathrm{F}_{4,12}=265.904, \mathrm{p}=1.337 \times 10^{-11}\right)$ were significant factor and interaction that influence adsorption of the pollutant at $90 \%$ confidence level

\section{ACKNOWLEDGEMENT}

The authors wish to acknowledge the following people Mr Adegoke Akinola, and Late Kareem of Central Science Laboratory, Obafemi Awolowo University, Ile - Ife and Mr. Adisa of BOWEN Central Science Laboratory, Iwo, Oludamilare Florentin Ogundeji (CVE/2014/060), Adeyeye Emmanuel Ademiju (CVE/2014/050), Femi John Adewale (CVE/2014/051) and Agbogunleri Olamide Jubril of Department of Civil Engineering, Obafemi Awolowo University, Ile-Ife (Nigeria) for their roles in the determination of lead concentrations and procurement of PCCs used in the study respectively.

\section{REFERENCES}

Adie, D. B.; Olarinoye, N.O.; Oke, I. A.; Ismail, A and Otun, J. A (2009). Removal Of Lead Ions From Aqueous Solutions Using Powdered Corn Cobs. Canadian Journal ofChemical Engineering. 88:241-255

Akaike, H. (1976). An information criterion (AIC), Math. Sci. 14:1-5.

Aksu, Z, (2002). Determination of the equilibrium, kinetic and thermodynamic parameters of the batch biosorption of nickel (II) ions onto Chlorella vulgaris. Process. Biochem. 38: 89-99.

Alam, Z. M.D; Muyibi, S.A; Mansor, M.F and Wahid, R (2007). Activated Carbons derived from oil palm empty fruit bunches: Application to environmental problems. Journal of Environmental Sciences. 19(1): 103-108

Amoko, J. S., Obijole O. A., Fehintola, E. O, Oke, I. A., Adeosun, O.O., Ojo, S. O., Bolorunduro, K. A., Foghi, P. U., Amele S. O., and Adegbite, A. A (2015). Evaluation of Linear Regression Equations and Methods of Solving Linear Equations: Adsorption Kinetics Model. Direct Research Journal of Engineering and Information Technology. 3(2): 7-30

Amoko, J. S; Fehintola, E. O; Obijole, O. A and Oke, I. A. (2016). Mechanisms and modelling phosphate removal from textile wastewaters by chemical coagulation. Direct Research Journal of Chemistry and Material Science. 4(1): $1-13$

APHA, (1998). Standard Method for the Examination of Water and Wastewater, 
20th edn, America Water Works Association and Water Pollution Control Federation, Washington DC.

Arellano, O., Flores, M., Guerra J., Hidalgo A., Rojas D., and Strubinger, A., (2016). Hydrothermal carbonization (HTC) of corncob and characterization of the obtained hydrochar, Chemical Engineering Transactions. 50: 235-240

Barati, R (2013) Application of Excel Solver for Parameter Estimation of the Nonlinear Muskingum Models. KSCE Journal of CivilEngineering. 17(5):1139-1148

Edson, L. F. , Gabriela, C. C. , Marcio, A. M. and Sérgio, L. J. (2011). Adsorption of Textile Dye on Zinc Stannate Oxide: Equilibrium, Kinetic and Thermodynamics Studies. Separation Science and Technology. 46:2510-2516

Erhan, D; Kobya, M; Elif, S, and Ozkan, T, (2004). Adsorption kinetics for the removal of chromium III from aqueous solutions on the activated carbonaceous prepared from agricultural wastes. Water SA. 30(4): 533540.

Fehintola, E. O, Amoko, J. S, Obijole, O. A. and Oke, I. A. (2015b). Pseudo second order kinetics model of adsorption of $\mathrm{Pb}^{2+}$ onto powdered corn cobs: comparison of linear regression methods. Direct Research Journal of Chemistry and Material Science(DRCMS). 3(1):1-16.

Fehintola, E. O.; Obijole, O. A.; Amoko , J. S. and Oke , I. A. (2015a). Adsorption Equilibrium Isotherms Of $\mathrm{Pb}, \mathrm{Ni}$ And Cd Onto Powdered Egg Shells. Ife Journal of Science. 17(1): $141-162$

Hanafiah, M.A; Ngah, K.M; Ibrahim, S.C; Zakaria, H and Ilias, W.A.H.W (2006). Kinetics and thermodynamics of lead adsorption from aqueous solution onto Rubber (Hevea brasiliensis) leaf Powder. Journal of Applied Sciences. 6(13): 27622767.

Ho, Y.S (2007). Bibliometric Analysis of Adsorption Technology in Environmental Science. Journal of Environmental Protection Science. 1: 111.

Hui, Z., Xue, Z., Luobin W., Kai, W. and Wendong,
W. (2018) Development of a software tool for teaching real-time state simulation of water distribution networks, Computer Applications in Engineering Education. 26 (3): 577-588.

Ismail, A; Adie, D.B.; Oke, I. A.; Otun, J.A; Olarinoye, N.O. ; Lukman, S. and Okuofu, C.A. (2009). Adsorption Kinetics of Cadmium Ions Onto Powdered Corn Cobs. Canadian Journal of Chemical Engineering. 87: 896-909

Izanloo, H and Nasseri , S. (2005), Cadmium Removal from Aqueous Solutions by Ground Pine Cone. Iranian J Env Health Sci Eng, Iranian J Env Health Sci Eng. 2 (1):33-42

Ogunjobi, J. K and Labunmi, L. (2013). Characterisation of Bio-Oil and Bio-Char from Slow-Pyrolysed Nigerian Yellow and White Corn Cobs. Journal of Sustainable Energy E Environment. 4: 77-84

Oke, I. A. ; Ismail, A. ; Lukman, S. ; S. O. Ojo, O. O. Adeosun, and M. O. Nwude (2016). Economics and Statistical Evaluations of Using Microsoft Excel Solver in Pipe Network Analysis. J. Pipeline Syst. Eng. 7(4): 06016002-1- 9

Oke, I. A. ; Olarinoye, N.O. and Adewusi, S.R.A. (2008). Adsorption Kinetics for Arsenic Removal by Untreated Powdered Eggshell from Aqueous Solutions. Journal of Adsorption Society. 14(1): 85-92

Oke, I. A.; Lukman, S. and Ismail, A (2017). Development and Performance Evaluation of A New Numerical Model for Groundwater Recharge Estimation. Nigeria Journal of Engineering. 23(2): 56 -65 .

Okoronkwo, E.A., Imoisili, P.E., Olubayode, S.A. and Olusunle, S.O.O. (2016). Development of Silica Nanoparticle from Corn Cob Ash. Advances in Nanoparticles. 5: 135-139.

Otun, J.A; Oke, I.A; Olarinoye, N.O; Adie, D.B and Okuofu, C.A (2006a). Factors that influence Adsorption Using $2^{\mathrm{k}}$ Factorial Experiment. Journal of Applied Sciences. 6(11):2432- 2437.

Otun, J.A; Oke, I.A; Olarinoye, N.O; Adie, D.B and Okuofu, C.A (2006b). Adsorption 
isotherms of $\mathrm{Pb}(\mathrm{II}), \mathrm{Ni}(\mathrm{II})$ and $\mathrm{Cd}$ (II) onto PES. Journal of Applied Sciences. 6 (11):2368- 2376.

Tay, K. G; Kek, S. L. and Rosmila A. K. (2014). Solving Non-Linear Systems by Newton's Method Using Spreadsheet Excel.

van Loosdrecht, M.C.M., Nielsen, P.H.,LopezVazquez, C.M., and Brdjanovic, D., (2016). Experimental Methods in Wastewater Treatment. 1st Edition, International Water Publishing Alliance House, London.

Wanitwattanarumlug, B.; Luengnaruemitchai, A and Wongkasemjit, S. (2012). Characterization of Corn Cobs from
Microwave and Potassium Hydroxide Pretreatment. International Journal of Chemical and Biological Engineering 6:1-8.

Wuyep, P. A; Chuma, A. G.; Awodi, S. and Nok, A. J. (2007). Biosorption of Cr, Mn, Fe, Ni, $\mathrm{Cu}$ and $\mathrm{Pb}$ metals from petroleum refinery effluent by calcium alginate immobilized mycelia of Polyporus squamosus. Scientific Research and Essay. 2 (7): 217 221.

Yun, J.H; Park, H.C and Moon, H (1996) Multi component Adsorption Calculations based on Adsorbed Solution Theory. Korean J. Chem. Eng., 13(3): 246-254. 